\title{
Editorials
}

\section{What have we really learned from SARS?}

\author{
Michelle Chiu MD, Homer Yang MD, Joseph Po MD, Earl Wynands OC MD
}

$\mathrm{I}$ T has been two years since severe acute respiratory syndrome (SARS) first hit Canada. In this issue, Caputo et al. not only provide documentation of the events at that time but also give us an opportunity to reassess what we can learn from this episode. ${ }^{1}$

We are often reminded that to ignore history is to repeat its mistakes. In the early 1980s, patients presented with unusual infections and Kaposi sarcomas; healthcare workers struggled with the beginnings of the acquired immunodeficiency syndrome epidemic, learning the natural history of the illness "on the fly", and at no small peril. The sense of "coping" and "flying by the seat of one's pants" was again present during the SARS epidemic. With increasing globalization, it is not a question of "if", but of "when" another epidemic will be here.

From the SARS experience, there appear to be a number of issues worth revisiting. During the initial outbreak of SARS, the monitoring and announcement of a potential epidemic was far from efficient. It would appear that the World Health Organization and the Center for Disease Control have since increased their surveillance and the speed of reporting on potential epidemics.

Caputo et al. were able to document the sense of communication gaps between policy makers and frontline healthcare workers during SARS. The healthcare workers expressed a level of frustration, as their expertise and experience were not effectively integrated into policies. It is not uncommon, and not unexpected, that experts in infectious disease are less informed of the procedures in frontline areas, e.g., critical care or operating rooms, than personnel working in those areas. In future epidemics, how does one ensure that policy makers such as infectious disease experts take into account these procedural considerations in an effective and expeditious fashion?
The proper use of personal protective equipment (PPE) is difficult to attain at the best of times. Are we asking for the impossible when healthcare workers, after a "crash course" in PPE, have to perform complex tasks in life-threatening situations? In the midst of the epidemic, a large group of healthcare workers: physicians, nurses, and respiratory therapists, had to be trained. Should a smaller group be trained as the initial response team with a wider group of healthcare workers trained subsequently, albeit at a slower rate, in the event of another epidemic?

Epidemics present huge logistical problems; SARS was no different. During a cardiac arrest, in their PPE, healthcare providers discovered that they couldn't use a stethoscope. Nor could they hear each other well when wearing PPE. Nor did they know that starting iv lines was a challenge while double-gloved and suited up. The simple act of correctly and efficiently donning and removing the personal protective Stryker suits was a continual challenge.

Military forces all over the world have used simulation technology for operational and disaster training. ${ }^{2-4}$ The Canadian military categorizes simulation into technical, tactical, and strategic components. Technical simulation familiarizes troops with basic equipment and how to use it (i.e., weapons drills). Tactical simulation focuses on procedures and small-unit team coordination and communication skills (i.e., mass casualty exercises, specialized squad tactical exercises). Finally, strategic simulation is used to produce and evaluate strategic options (i.e., overseas deployment operations, war games). It would seem many lessons could be learned from this model and applied to the medical field of infectious disease disaster planning.

From a technical point of view, the practical, clinically relevant aspects of using PPE should be worked out and practiced. Many of these problems are well described in the article by Caputo et al. in this issue. ${ }^{1}$

From the Department of Anesthesia, University of Ottawa, Ottawa, Ontario, Canada.

Address correspondence to: Dr. Homer Yang, Department of Anesthesia, Room B309, Ottawa Hospital, Civic Campus, 1053 Carling

Avenue, Ottawa, Ontario K1Y 4E9, Canada. Phone: 613-761-4940; Fax: 613-761-5032; E-mail: hyang@ottawahospital.on.ca 
Team training in the local hospital environment is critical to success. It is one thing to practice donning the PPE at one's leisure. But to do it correctly and in a time-efficient manner when under the pressure of running a cardiac or respiratory arrest is a completely different story. The logistics of transferring a critically ill patient to the intensive care unit is often challenging enough without the added burden of treating a potential SARS patient. The question of whether simulation improves team performance is still being debated in the simulation literature. ${ }^{5}$ However, there is an abundance of evidence that technical skills can be improved by simulation training. ${ }^{6,7}$ The logistics of complex medical acts in a SARS patient, such as intubation, defibrillation and patient transfer, can only be elucidated when they are practiced in real time, with all team members present. Simulation can play a vital role in this regard.

Some of the strategic issues have been alluded to above. Perhaps the most important issue is the structuring of multidisciplinary teams in a meaningful way. Of course, it is provocative to consider the utility of a citywide or a regional simulation of a SARS-like epidemic; with increasing concerns of terrorism, the idea is not without merit.

If simulation is to be employed in addressing these concerns, it is not without genuine difficulty. The type of simulation: strategic, technical, or tactical, and the integration of these simulations are questions unanswered in civilian situations. The capital equipment and operating costs must be generated. Access to simulation technology may be a challenge. When and how often should the team practice be in order to maintain competence? Are the skills learned in simulation transferable to clinical practice and what is the impact of such training on patient care? These are questions of constant debate in the medical simulation literature and they remain to be answered.

There are a number of ways to approach the lessons we learned from SARS. The role of medical simulation in improving patient safety is still being defined. In this instance however, it can be argued that simulation has a definite role in improving health care worker safety. In the lull between storms, we should reflect upon and anticipate preparations for the next epidemic. At this point, the prevailing sense is one of being reactive rather than proactive.

\section{Qu'avons-nous réelle- ment appris du SRAS ?}

Il y a deux ans, le syndrome respiratoire aigu sévère (SRAS) est apparu pour la première fois au Canada. Dans le présent numéro, Caputo et coll. présentent les événements de cette période et donnent aussi l'occasion de réévaluer ce que nous avons appris de cette crise. $^{1}$

On nous rappelle souvent que d'ignorer l'histoire, c'est s'exposer à en répéter les erreurs. Au début des années 1980, des patients étaient atteints d'infections inhabituelles et de la maladie de Kaposi ; les travailleurs de la santé commençaient alors la lutte au syndrome d'immunodéficience acquise, apprenant «sur le tas» et non sans grand danger l'histoire naturelle de la maladie. Cette impression de «se débrouiller» et «d'agir intuitivement» était de nouveau présente pendant la crise du SRAS. Avec la progression de la mondialisation, la question n'est pas «si», mais bien «quand» une autre épidémie va survenir.

De l'expérience du SRAS, un certain nombre d'enjeux méritent d'être repensés. Au début de la flambée de SRAS, le contrôle et l'annonce d'une épidémie potentielle étaient loin d'être efficaces. Depuis lors, l'Organisation mondiale de la santé et le Center for Disease Control semblent avoir amélioré leur surveillance et la vitesse de signalement d'épidémies potentielles.

Caputo et coll. ont pu documenter l'impression d'absence de dialogue et d'informations entre les décideurs et le personnel de soins de première ligne pendant le SRAS. Les travailleurs de la santé ont exprimé leur frustration, car leur expertise et leur expérience n'ont pas été efficacement intégrées aux politiques. Il n'est pas rare, ni surprenant, de constater que les experts en maladies infectieuses sont moins informés sur les protocoles des unités de première ligne, comme les soins intensifs ou les salles d'opération, que le personnel qui y travaille. Comment s'assurer, lors de prochaines épidémies que les décideurs, comme les experts en maladies infectieuses, tiendront compte de ces éléments de manière efficace et rapide ?

Il est difficile d'apprendre le bon usage de l'équipement de protection individuelle (EPI) dans les meilleures circonstances. Alors, demandons-nous l'impossible au personnel de soins qui, après un «cours intensif» sur l'EPI, doit réaliser des tâches complexes et met sa vie en danger ? Au cœur de l'épidémie, un groupe important de travailleurs de la santé, médecins, 
personnel infirmier et inhalothérapeutes, ont dû recevoir une formation. Devrait-on former un petit groupe qui soit la première équipe d'intervention, puis un groupe plus important par la suite, mais à un rythme plus lent, dans l'éventualité d'une autre épidémie ?

Les épidémies présentent des problèmes de logistique énormes; le SRAS n'était pas différent. Pendant un arrêt cardiaque, les soignants, dans leur EPI, ont découvert qu'ils ne pouvaient utiliser de stéthoscope. Ils ne pouvaient se faire entendre les uns des autres et, vêtus d'une double paire de gants et d'un survêtement, l'installation d'un cathéter iv était tout un défi. Le simple geste de mettre et d'enlever correctement et efficacement le système de protection individuelle était une prouesse en soit.

Les forces armées à travers le monde ont utilisé la simulation pour l'entraînement opérationnel et les plans de secours..$^{2-4}$ Les militaires canadiens classent la simulation en catégories technique, tactique et stratégique. La simulation technique familiarise les troupes avec le matériel de base et la façon de l'utiliser (le maniement des armes). La simulation tactique est centrée sur les modes d'opération et la coordination des équipes de petites unités et sur les habiletés de communication (exercices en cas de nombreux blessés, exercices stratégiques d'escouades spécialisées). Enfin, la simulation stratégique permet de faire les choix stratégiques et de les évaluer (les opérations de déploiement outre-mer et les jeux de guerre). On peut beaucoup apprendre de ce modèle et l'appliquer à la planification en cas de maladies infectieuses.

D'un point de vue technique, les aspects pratiques et cliniquement pertinents de l'usage de l'EPI doivent être définis et pratiqués. Nombre de ces problèmes sont bien décrits dans l'article de Caputo et coll. ${ }^{1}$

Une formation en équipe dans le cadre de l'hôpital local est indispensable au succès. C'est une chose de revêtir l'EPI pour s'exercer. Mais bien le faire en peu de temps, sous pression, en cas d'arrêt cardiaque ou respiratoire, est une toute autre histoire. La logistique du transfert d'un patient gravement malade à l'unité des soins intensifs est souvent assez exigeante sans y ajouter la charge d'un cas potentiel de SRAS. Quant à savoir si la simulation améliore la performance de l'équipe, c'est un sujet toujours débattu dans les publications. ${ }^{5} \mathrm{Il}$ y a pourtant une preuve abondante de l'amélioration des habiletés techniques par la simulation. ${ }^{6,7} \mathrm{La}$ logistique d'actes médicaux complexes chez le patient atteint du SRAS, comme l'intubation, la défibrillation et le transfert du patient, peut être clarifiée par un entraînement en temps réel seulement et en présence de tous les membres de l'équipe. La simulation peut jouer un rôle vital à cet égard.
Concernant certaines questions stratégiques déjà abordées, le point le plus important est peut-être de structurer les équipes multidisciplinaires d'une manière rationnelle. On peut être perplexe face à l'utilité de simuler une épidémie comme celle du SRAS à travers une ville ou une région, mais avec l'inquiétude croissante au sujet du terrorisme, l'idée n'est pas sans mérite.

$\mathrm{Si}$ la simulation doit être employée en abordant ces enjeux, ce n'est pas sans de véritables difficultés. Le genre de simulation, stratégique, technique ou tactique, et l'intégration de ces simulations, sont des questions non résolues dans les situations civiles. Les biens d'équipement et les frais d'exploitation doivent être évalués. L'accès à la technologie de la simulation peut être un défi. Quand et à quelle fréquence l'équipe doit-elle s'entraîner afin de maintenir sa compétence ? Est-ce que les habiletés acquises lors de la simulation sont transférables à la pratique clinique et quelles sont les répercussions de cet entrainement sur les soins aux patients? On en discute encore dans les publications médicales sur la simulation et les réponses tardent à venir.

Il y a un certain nombre de façons d'aborder les leçons apprises du SRAS. Le rôle de la simulation médicale dans l'amélioration de la sécurité du patient n'est pas encore défini. Dans le cas présent, toutefois, on peut affirmer que la simulation joue certainement un rôle dans l'amélioration de la sécurité du personnel de soins. Pendant l'accalmie entre les tempêtes, nous devrions penser à nous préparer à la prochaine épidémie et à la prévenir. En ce moment, l'impression dominante est que nous sommes réactifs plutôt que proactifs.

\section{References}

1 Caputo KM, Byrick R, Chapman MG, Orser BJ, Orser $B A$. Intubation of SARS patients: infection and perspectives of healthcare workers. Can J Anesth 2006; 53: 122-9.

$2 M c$ Carthy $M$. US military revamps combat medic training and care. Lancet 2003; 361: 494-5.

3 Kyle RR, Via DK, Lowy RJ, Madsen JM, Marty AM, Mongan PD. A multidisciplinary approach to teach responses to weapons of mass destruction and terrorism using combined simulation modalities. J Clin Anesth 2004; 16: 152-8.

4 Berkenstadt H, Ziv A, Barsuk D, Levine I, Cohen A, $\operatorname{Vardi} A$. The use of advanced simulation in the training of anesthesiologists to treat chemical warfare casualties. Anesth Analg 2003; 96: 1739-42.

5 Shapiro MJ, Morey JC, Small SD, et al. Simulation based teamwork training for emergency department 
staff: does it improve clinical team performance when added to an existing didactic teamwork curriculum? Qual Saf Health Care 2004; 13: 417-21.

6 Rowe R, Cohen RA. An evaluation of a virtual reality airway simulator. Anesth Analg 2002; 95: 62-6.

7 Barsuk D, Ziv A, Lin G, et al. Using advanced simulation for recognition and correction of gaps in airway and breathing management skills in prehospital trauma care. Anesth Analg 2005; 100: 803-9. 